\title{
correspondence
}

\section{The laetrile question}

SIR,-There is no lack of "freedom to use harmless drugs", but freedom to promote and sell worthless remedies is constrained. Laetrile (which is not harmless), is the latest and most ingeniously promoted of a long string of such money makers. Croft's first consideration (14 July, page 100) implies that because scientists have been wrong before, therefore they are wrong this time. It is a favourite ploy of laetrile promoters' modesty to compare themselves with the Wright brothers, Louis Pasteur and other shatterers of precedent.

His second consideration, the "resentment of the wealth that medical doctors extract" is an example of the "principle of compensatory evil". Apparently it is alright for doctors to make money by prescribing laetrile. His third point seems to imply that the consumption of a cyanogenic glycoside is part of the pursuit of happiness. Unfortunately, the quest sometimes ends with the use of a stomach pump.

Would Jukes turn people away from Lourdes? Alas, I might if the admission fee were $\$ 1,500$, coupled with a promise to cure cancer.

Yours faithfully, Thomas H. JuKes

\section{Nutrition planning}

SIR,-In his attack on the present state of nutrition planning (30 June, page 742), Donald McLaren makes some characteristically trenchant points regarding the nature of the world's food 'problem', but seems to be attacking the wrong target. Surely the failure of the Green Revolution, as failure it probably is, is a classic case of the nonholistic, piecemeal approach which he advocates. It was precisely because (for reasons not unconnected with that inelegant term, agripower) no thought was given to the economic, educational and organisational needs associated with introduction of improved crop varieties, that the increased potential yields of these varieties did not manifest themselves as improved nutrition for the mass of poor consumers.

To implement lasting improvements in nutrition, it is surely necessary to investigate not only biochemistry, but also land tenure, demography, the availability of water and fertilisers, political power-mongering and so on, for the relevant area. Such an analysis is, by definition, holistic. As McLaren himself points out "the widespread problem (....) has socio-economic roots".

I share McLaren's doubts regarding "Uitopian social engineering" and "holistic day-dreaming"; similarly the systems engineering approach of the space programme is likely to be totally inappropriate in tackling nutritional problems. Despite this, a broader approach to the study of nutrition, involving economic and institutional factors, even, possibly, the occasional maze of flow diagrams, seems to be essential. This is certainly the approach adopted in our 1978 Open University course, Food Production Systems, of which McLaren's paper on 'The great protein fiasco' (Lancet 93-6 1974), forms an integral part. Yours faithfully,

\section{R. M. Morris}

Open University, Milton Keynes, UK

\section{Unemployed scientists}

SIR,-I agree with Dr Klein's comments (23 June, page 665) and would like to raise a related issue. The dire problem of post-PhD employment is still to be fully debated in Britain. The number of qualified scientists in their late twenties and early thirties with no permanent job is rising fast, especially in biology. Universities seem to be passing such people over when filling posts recently, and the reasons for this are twofold: young (ie early twenties) post doctoral job applicants are cheaper to employ and, perhaps

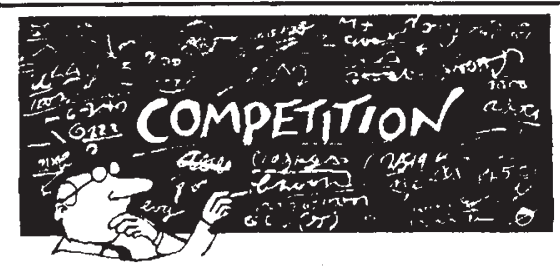

Competition 14. $£ 10$ for the most stultifying, dreary or meaningless paragraph or two on any theme or non-theme (either published or of your own invention). The second leader of Nature 258, page 465 (11 December, 1975) may serve as an example. Closing date : 26 August.

Competition 13 asked for a technological message to a less advanced more insidious, there is a feeling that older candidates may compete for seniority with their longer employed, colleagues of equal age.

In the long term, such practices must be harmful to the academic community. In few other countries can an individual of 23 or 24 years of age, even perhaps five years older, be regarded as intellectually mature enough to acquire a permanent post tenable for the remainder of his working lifie. Here in Germany for example, the normal procedure is to spend up to six years as an Assistent before competing for a permanent university post.

I would like to see a list of senior, non-tenured scientists drawn up for each discipline, and circulated to the relevant university departments. Any $\mathrm{PhD}$ would be eligible to join this list at age thinty or so. Before advertising any post, the university concerned should first consider senior scientists on the list, and should offer the job to any suitable candidate thereby found. If none are eligible, then the post could be freely advertised.

By using a system of this kind, the backlog of skilled labour would rapidly be incorporated. Post doctoral research funds would take care of younger people waiting their turn, and an accompanying drastic decrease in $\mathrm{PhD}$ student numbers for the next few years would help shorten the queue.

Yours faithfully,

ROBERT RANSOM

Visiting Scientist,

Institut für Biologie II,

Universität Freiburg,

West Germany

civilisation out in space. Jeanne Hopkins, on the staff of the Astrophysical Journal in Chicago, was a clear winner with the following:

'Congratulations on inventing the wheel! Yes, we do realise that all the tedious manual labour-was performed by your grad students - but the idea was yours, and that's what counts. As you have no doubt informed your Grants Committee, your invention will revolutionise warfare; however, massive Government funding will be required to bring it to its full capability. We suggest that you submit a detailed proposal to your government, outlining possible modifications and improvements, along with a target date for each For example: "Round wheel, target date 30 years. Toothed wheel, 300 years. White sidewalls, 3,000 years." 